\title{
ANIMAL ASSISTED THERAPY IN CHILDREN WITH DISABILITIES
}

\begin{abstract}
Although the term animal assisted therapy is relatively new, the use of animals to overcome disease or a condition in humans is not a new idea. The earliest use of animals for therapeutic purposes was noticed in Belgium, where animals and humans were rehabilitated together, and animals were an important part of human natural therapy.

The application of various therapies and activities with children with disabilities in order to improve their overall condition and the implementation of daily activities is expanding. One of the modern approaches in the treatment of children with disabilities is canine assisted therapy and focuses on improving a person's physical, cognitive and socio-emotional functioning.

Our research was organized in a quasi-experimental format, there were control and experimental groups, including children with motor disorders, speech problems and children with behavioural problems. The control group underwent classical treatment with a special educator and rehabilitator, while the experimental group received dog assisted therapy.

Researches indicate that the presence of a dog during the therapies helps children improve their mood, increases their will to actively participate, have easier emotional expression, improves or overcomes speech disorders, encourages communication, improves psychomotor development and achieves a range physiological benefits.
\end{abstract}

Keywords: THERAPY, ANIMALS, DOG, DISABILITY, DEVELOPMENTAL, ACQUISITION

\section{Introduction}

Historically, the first recordings of the animal contribution to the human welfare date back to the 1600 year, when John Lock wrote in his discussions about the use of small animals in order to develop empathy and responsibility in children (Fine, 2000). Animal housing and domestication began more than 2 million years ago, and in the Ancient Greece emotional and physical benefits of the contact with animals were noticed. In the year of 1792 in England the farm animals were used in the treatment of mentally ill patients, in order to reduce the isolation and restrictions (Baun \& McCabe, 2000). Later in Germany, animals were used in therapeutic goals in the institutions for mentally ill and homeless people, and in 1942 animals were used for the treatment and healing of the war invalids in America. In 1960 year the human animal bond was con- 
ceptualized by a psychologist Boris Levinson, and he created the term animal assisted therapy, by using his dog while working with a withdrawn and mentally impaired young boy and noticed significant positive changes (Levinson, Mallon, 1997).

The dog is the first animal that the human domesticated and kept at home. In a 14.000 years old tomb in Israel, the remains of a man lying with one hand on the chest of a small dog were found, and the domestication also began in Israel 12.000 years ago. The history of human evolution is believed to be directly related to the evolution of dogs, believing that it caused functional changes in the human brain. The use of dogs in the treatment of persons with disabilities was noted in the middle century in Belgium. Since the 1970s when the dog assisted therapy was introduced in clinical conditions, such a treatment was offered in therapeutic centres, special needs programmes, hospitals, nursing homes for elderly, prisons and institutions for mental health, without any age boundaries. It is effective for children, adolescents, adults and elderly (Alliance of therapy dogs, 2018).

\section{Types of the animal assisted interventions}

An animal assisted intervention is each intervention that intentionally involves animals as part of a therapeutic process. Such interventions are commonly used in patients with physical problems, intellectual, psychic, neurologic and motor impairments, but can also be used in people with depression, anxiety, posttraumatic stress etc. There is a need for examinations and evaluations before each implementation, in order to determinate the possible contraindications. The implementation of the intervention can require multidisciplinary approach with different tasks and responsibilities, depending of the intervention. The animal assisted interventions are divided in three categories (AVMA, 2019):

1. Animal assisted therapy - an intervention used as support to other therapies (co-therapy) focuses on the treatment of physical problems, intellectual, psychic, cognitive, emotional, attachment, neurological and motor impairments.

2. Animal assisted education - educational and/or rehabilitation intervention intended for healthy, but also persons with disabilities, with behavioural disorders. The intervention aims to improve the psychophysical and social wellbeing and the quality of life of the persons, increasing their self-esteem. The animals are used for the behavioural re-education. Such intervention is commonly used in the prolonged or recurrent hospitalizations in rehabilitation centres, attachment problems in the childhood or adolescence, emotional disturbances, behavioural disorders and sociocultural adaptation.

3. Animal assisted activity - episode, recreational intervention intended for healthy persons and persons with disabilities, in order to improve 
their quality of live. The animal bond in the activities presents a source of knowledge and sensory-emotional stimulation. In some cases animal assisted activities are an introductory step in the education or therapy and aim to develop skills through animal care, increasing responsibility, and stimulating motor activity.

In general, all three categories of interventions are performed by a multidisciplinary team, where each member is trained for the animal assisted intervention. The animal used in the intervention is previously entirely examined by the veterinarian, and his/her behaviour is monitored during the whole intervention. All animals included in the interventions, especially those exposed to direct contact and activities, have to be trained and educated on specific skills, in order to acquire the necessary competencies.

The most common intervention is canine (dog) assisted intervention, an animal that is most often present in people's lives. In addition, the intervention is not just a walk with the dog or a game, it is a planned programme where the individual engages with the animal in a focused, previously specified and detailed programme. (Kruger \& Serpell, 2006). In canine assisted interventions there are three types of interventions:

1. Dogs for therapeutic visits: these are pets that owners occasionally bring to visit patients who have been hospitalized for a long time in hospitals, nursing homes, rehabilitation institutions. Dogs improve their psychophysical condition. According to research, contact with dogs causes the production of oxytocin (a hormone of connection), dopamine (a hormone of happiness) and decreases the amount of cortisol (a stress hormone).

2. Dogs used as mediators in the treatment and rehabilitation: help physiotherapists, occupational therapists, special educators and rehabilitators, speech therapists in the realization of the treatment goals. They enable the improvement in the gross and fine motoric, visio-motor coordination, balance, speech, interaction.

A new type of intervention is the "Reading to Dogs" technique. The programme is designed to help the enlarged number of children with reading and language skills difficulties to build and develop verbal skills and vocabulary, improve reading comprehension, and develop self-confidence. Dogs are passive listeners that do not criticize or suggest, have enough time to listen without condemnation and act in a motivational, stimulating, calming manner (Pillow-Price et all., 2014).

3. Service dogs: these dogs usually work in nursing homes or hospice and are well trained to help the users in the realization of their daily obligations, without dependence on another person. In the past years there were several different types of service dogs: 
- A dog guide for blind;

- A dog alert for the deaf people;

- A dog wheelchair guide for physically disabled people;

- A diabetic alert dog;

- An epileptic seizure alert dog;

- Dogs that help in epileptic seizures;

- Psychiatric dogs;

- Dogs for supporting children with autism spectrum disorder;

- Dogs for the detection of allergens.

No matter what form of intervention is used, dogs used should always be well-trained and prepared for different situations and contacts with people. Dogs can be of different breeds and of different character, but they all must have certain characteristics necessary for the successful implementation of the intervention: to be calm, stable (not explosive), not to be aggressive, to be able to inhibit their impulses, to cope with unpredictable situations (slippery floor, strong odours, loud noises, etc.) tolerant of hugging and strangers, to have a desire to play and cooperate. Before training, dogs are evaluated, in addition to physical examination and age, their character and relationship with the guardian is assessed. Dog training lasts from 6 weeks for therapeutic visits and reading up to 18 months for various services (Clonowski, 2015).

\section{Methodology of research}

The aim of the study was to determine the impact of the presence of the animal - the dog, during the treatment of children with developmental disabilities, that is, to see if the inclusion of dogs in the therapy of children with various types of disabilities will give better results in a shorter time than the classical treatment. Until now, in our country, in the Republic of North Macedonia, dog therapy has not been performed in children with disabilities, which means that in this part we are pioneers. The research was conducted through a quasiexperiment over a period of three months, with a control and experimental group, each consisting of three students with developmental disabilities, previously assessed, evaluated and proportionally distributed in the groups. The experimental group underwent dog therapy, while the control group underwent classical special education and rehabilitation treatment. Before the start of the treatment, a control assessment of the motor, speech-language abilities and the behaviour during the daily activities of the children was made and based on the results, therapeutic programmes were prepared, that is work plans with precisely defined goals, methodological procedures and resources. The same assessments were performed on half of the treatment (after 1.5 months) and at the end of the treatment. Quasi-experimental checklists and transcripts of video and image data were used to collect data, which we realized through the ATLAS.ti programme (a programme for qualitative analysis of textual, graphic, 
audio and video data). First, we compared the effects of the exercises with and without the use of a dog, and then we made a comparison with other similar research. We compared the changes in the results with the Difference-in-differences (DID) technique, while the assessments were made using the Adaptive Behaviour Assessment System (ABAS) (Harrison \& Oakland, 2000-2003). Scale scores are represented by a specific range in a quantitative scale such as: extremely low, marginal, below average, average, above average, superior, very superior.

The research was conducted at the Pet Center "AvAv Happy Dog" in Skopje, the sample consisted of 6 children with special needs, aged between 7 and 9 years, two respondents from each category (motor disorders, speech and communication disorders and difficulties in the realization of daily activities).

\section{The results analysis and discussion}

The initial assessments in the respondents determined results in line with the type and degree of disability, in children with motor impairment the weakest result was achieved in the field of motor skills - extremely low, communication was also affected as a result of spasm of the muscles of the speech apparatus, while socialization is well graded. In respondents with speech disorders, the weakest result was achieved in the field of communication - below the average, motor skills and socialization are on the border, while in respondents with behavioural problems, motor skills are developed according to their age, but communication and socialization are below the required average.

Table 1. The results of the first assessment

\begin{tabular}{|c|c|c|c|c|c|c|}
\hline $\begin{array}{l}\text { Exami- } \\
\text { nee }\end{array}$ & Domain & Sum score & $\begin{array}{l}\text { Percentile } \\
\text { score }\end{array}$ & $\begin{array}{l}\text { Result } \\
\text { of the } \\
\text { general } \\
\text { adapt. } \\
\text { compos } \\
\text {. (GAC) }\end{array}$ & $\begin{array}{c}\text { Confi- } \\
\text { dence } \\
\text { inter- } \\
\text { val }\end{array}$ & $\begin{array}{l}\text { Qualita- } \\
\text { tive range }\end{array}$ \\
\hline $\begin{array}{l}\text { A.E } \\
\text { motor }\end{array}$ & Motoric & 14 & 0.5 & 61 & $<70$ & $\begin{array}{c}\text { extremely } \\
\text { low }\end{array}$ \\
\hline \multirow[t]{2}{*}{$\begin{array}{l}\text { impair- } \\
\text { ments }\end{array}$} & $\begin{array}{l}\text { Communi- } \\
\text { cation }\end{array}$ & 20 & 21 & 88 & $80-89$ & $\begin{array}{c}\text { below the } \\
\text { average }\end{array}$ \\
\hline & $\begin{array}{l}\text { Socializa- } \\
\text { tion }\end{array}$ & 29 & $>90$ & 120 & $120-129$ & superior \\
\hline \multirow{3}{*}{$\begin{array}{c}\text { E.S } \\
\text { motor } \\
\text { impair- } \\
\text { ments }\end{array}$} & Motoric & 17 & 2 & 69 & $<70$ & $\begin{array}{c}\text { extremely } \\
\text { low }\end{array}$ \\
\hline & $\begin{array}{l}\text { Communi- } \\
\text { cation }\end{array}$ & 14 & 5 & 75 & $71-79$ & $\begin{array}{l}\text { border } \\
\text { line }\end{array}$ \\
\hline & $\begin{array}{l}\text { Socializa- } \\
\text { tion }\end{array}$ & 46 & $>90$ & 120 & $120-129$ & superior \\
\hline
\end{tabular}




\begin{tabular}{|c|c|c|c|c|c|c|}
\hline \multirow{3}{*}{$\begin{array}{c}\text { A.Sh } \\
\text { hearing } \\
\text { impair- } \\
\text { ments }\end{array}$} & Motoric & 63 & $>90$ & 111-131 & $71-79$ & $\begin{array}{l}\text { border } \\
\text { line }\end{array}$ \\
\hline & $\begin{array}{l}\text { Communi- } \\
\text { cation }\end{array}$ & 16 & 10 & 56 & $80-89$ & $\begin{array}{c}\text { below the } \\
\text { average }\end{array}$ \\
\hline & $\begin{array}{l}\text { Socializa- } \\
\text { tion }\end{array}$ & 22 & 53 & 91 & $90-109$ & $\begin{array}{c}\text { normal } \\
\text { line }\end{array}$ \\
\hline \multirow{3}{*}{$\begin{array}{c}\text { E.M } \\
\text { hearing } \\
\text { impair- } \\
\text { ments }\end{array}$} & Motoric & 62 & $>90$ & $119-131$ & $120-129$ & $\begin{array}{c}\text { border } \\
\text { line }\end{array}$ \\
\hline & $\begin{array}{l}\text { Communi- } \\
\text { cation }\end{array}$ & 6 & 0.2 & 25 & $\leq 70$ & $\begin{array}{c}\text { extremely } \\
\text { low }\end{array}$ \\
\hline & $\begin{array}{l}\text { Socializa- } \\
\text { tion }\end{array}$ & 20 & 47.3 & $83-89$ & $80-89$ & $\begin{array}{c}\text { below the } \\
\text { average }\end{array}$ \\
\hline \multirow{3}{*}{$\begin{array}{c}\text { Sh.B } \\
\text { behavioral } \\
\text { problems }\end{array}$} & Motoric & 51 & $>90$ & $111-131$ & $110-119$ & superior \\
\hline & $\begin{array}{l}\text { Communi- } \\
\text { cation }\end{array}$ & 13 & 3 & 47 & $\leq 70$ & $\begin{array}{c}\text { extremely } \\
\text { low }\end{array}$ \\
\hline & $\begin{array}{l}\text { Socializa- } \\
\text { tion }\end{array}$ & 12 & 10 & 56 & $\leq 70$ & $\begin{array}{c}\text { extremely } \\
\text { low }\end{array}$ \\
\hline \multirow{3}{*}{$\begin{array}{c}\text { D.M } \\
\text { behavioral } \\
\text { problems }\end{array}$} & Motoric & 47 & 82 & 105 & $90-109$ & superior \\
\hline & $\begin{array}{l}\text { Communi- } \\
\text { cation }\end{array}$ & 7 & 0.5 & 30 & $\leq 70$ & $\begin{array}{c}\text { extremely } \\
\text { low }\end{array}$ \\
\hline & $\begin{array}{l}\text { Socializa- } \\
\text { tion }\end{array}$ & 5 & 1 & 33 & $\leq 70$ & $\begin{array}{c}\text { extremely } \\
\text { low }\end{array}$ \\
\hline
\end{tabular}


Table 2. The results of the last assessment

\begin{tabular}{|c|c|c|c|c|c|c|}
\hline $\begin{array}{l}\text { Exami- } \\
\text { nee }\end{array}$ & Domain & Sum score & $\begin{array}{l}\text { Percen- } \\
\text { tile score }\end{array}$ & $\begin{array}{l}\text { Result of } \\
\text { the gen- } \\
\text { eral } \\
\text { adaptive } \\
\text { compos- } \\
\text { ite } \\
\text { (GAC) }\end{array}$ & $\begin{array}{l}\text { Confi- } \\
\text { dence } \\
\text { interval }\end{array}$ & $\begin{array}{c}\text { Qualita- } \\
\text { tive } \\
\text { range }\end{array}$ \\
\hline \multirow{3}{*}{$\begin{array}{c}\text { A.E } \\
\text { motor } \\
\text { impair- } \\
\text { ments }\end{array}$} & Motoric & 45 & 75 & 110 & $110-119$ & superior \\
\hline & $\begin{array}{l}\text { Communi- } \\
\text { cation }\end{array}$ & 29 & 50 & 100 & 90-109 & average \\
\hline & $\begin{array}{l}\text { Socializa- } \\
\text { tion }\end{array}$ & 48 & $>90$ & 120 & $120-129$ & superior \\
\hline \multirow{3}{*}{$\begin{array}{c}\text { E.S } \\
\text { motor } \\
\text { impair- } \\
\text { ments }\end{array}$} & Motoric & 23 & 9 & 80 & $80-89$ & $\begin{array}{c}\text { below } \\
\text { the aver- } \\
\text { age }\end{array}$ \\
\hline & $\begin{array}{l}\text { Communi- } \\
\text { cation }\end{array}$ & 25 & 32 & 92 & $90-109$ & average \\
\hline & $\begin{array}{l}\text { Socializa- } \\
\text { tion }\end{array}$ & 29 & $>90$ & 120 & $120-129$ & superior \\
\hline \multirow{3}{*}{$\begin{array}{c}\text { A.Sh } \\
\text { hearing } \\
\text { impair- } \\
\text { ments }\end{array}$} & Motoric & 63 & $\geq 90$ & 111-131 & $71-79$ & $\begin{array}{l}\text { border } \\
\text { line }\end{array}$ \\
\hline & $\begin{array}{l}\text { Communi- } \\
\text { cation }\end{array}$ & 25 & 32 & 80 & $80-89$ & superior \\
\hline & $\begin{array}{l}\text { Socializa- } \\
\text { tion }\end{array}$ & 25 & 86 & 107 & $90-109$ & average \\
\hline \multirow{3}{*}{$\begin{array}{c}\text { E.M } \\
\text { hearing } \\
\text { impair- } \\
\text { ments }\end{array}$} & Motoric & 62 & $\geq 97$ & $119-131$ & $120-129$ & superior \\
\hline & $\begin{array}{l}\text { Communi- } \\
\text { cation }\end{array}$ & 9 & 0.1 & 22 & $\leq 70$ & $\begin{array}{c}\text { ex- } \\
\text { tremely } \\
\text { low }\end{array}$ \\
\hline & $\begin{array}{l}\text { Socializa- } \\
\text { tion }\end{array}$ & 25 & $\geq 90$ & $108-131$ & $90-109$ & average \\
\hline \multirow{2}{*}{$\begin{array}{c}\text { Sh.B } \\
\text { behavioral } \\
\text { problems }\end{array}$} & Motoric & 55 & $\geq 90$ & $111-131$ & $110-119$ & superior \\
\hline & $\begin{array}{l}\text { Communi- } \\
\text { cation }\end{array}$ & 14 & 5 & 50 & $\leq 70$ & $\begin{array}{c}\text { ex- } \\
\text { tremely } \\
\text { low }\end{array}$ \\
\hline
\end{tabular}




\begin{tabular}{|c|c|c|c|c|c|c|}
\hline & $\begin{array}{c}\text { Socializa- } \\
\text { tion }\end{array}$ & 19 & 18 & $81-82$ & $80-89$ & $\begin{array}{l}\text { below } \\
\text { the aver- } \\
\text { age }\end{array}$ \\
\hline \multirow{3}{*}{$\begin{array}{c}\text { D.M } \\
\text { behavioral } \\
\text { problems }\end{array}$} & Motoric & 50 & $\geq 90$ & $108-131$ & $90-109$ & superior \\
\hline & $\begin{array}{l}\text { Communi- } \\
\text { cation }\end{array}$ & 12 & 2 & $40-41$ & $\leq 70$ & $\begin{array}{c}\text { ex- } \\
\text { tremely } \\
\text { low }\end{array}$ \\
\hline & $\begin{array}{c}\text { Socializa- } \\
\text { tion }\end{array}$ & 13 & 16 & $56-58$ & $\leq 70$ & $\begin{array}{c}\text { ex- } \\
\text { tremely } \\
\text { low }\end{array}$ \\
\hline
\end{tabular}

In the first group of examinees with motor impairments, we found that opposite to classic exercises, where after the last assessment the results for the motor abilities were at the extremely low level, including the dog in the rehabilitation process did not bring big and visible changes in the motoric development, but indicated some improvement in certain segments of the motor skills, which were on a border line, and the children showed perseverance and tried to complete the tasks and activities to the end. We can conclude that the animal assisted therapy motivates children to actively participate in the therapy, it increases their will and desire to work, and the improvement of the motor performances requires long-term and dedicated work to obtain measurable goals. Our findings overlap with the results of the Tepfer's research in 2017, according to which dog therapy plays an important role in motor skills, physical activity and quality of life. The authors concluded that the family dog could play a role in a healthy lifestyle in children with cerebral palsy. Dilek Elmaci and Sibel Cevizci in 2015 showed that dog therapy and activities can be a method of support for routine procedures for the rehabilitation of children with cerebral palsy, physical and intellectual disabilities.

Regarding the second group of examinees, who faced difficulties in the field of verbal skills and communication, the results of the last assessment showed improvement of the abilities and their movement in the border line. The results indicate that both therapies, classical exercises and dog assisted therapy, were effective, realizing and achieving certain goals, but as in the previous group, there is increased motivation and will, that is, when performing exercises with the dog included the children showed no signs of fatigue, unlike the children with whom we performed classical exercises. Emily HowellForbes (2014) in her study of the impact of dogs on the outcome of occupational therapy in children with cerebral palsy noticed significantly more vocalizations in respondents when the dog was present. In line with our findings are the results of LaFrance, Garcia \& Labreche in 2007, which show that verbal behaviours of patients can be improved by the presence of a therapeutic dog. Through intensive speech and language therapy in rehabilitation conditions by 
applying participatory observation, the researchers conclude that the presence of the dog has the potential to stimulate social-verbal and social-nonverbal communication.

In the third group of respondents, who had behavioural problems in the realization of daily activities and difficulties in interacting with peers, we found that the presence of a dog provides social connection child-dog-peer, improves children's interaction with each other and improves the overall behaviour of respondents. The best and most positive results from the whole research was obtained in the social domain. Katy R. Beck's research, through a survey of primary school teachers and staff, suggests that the presence of a dog can be a positive motivating tool for good behaviour and job performance in students. Therapeutic dogs allow children to feel safe and confident while performing the given tasks. Sabrina E.B. Schuck et al. shows that the dog intervention model influences the improvement in children's social skills and problem behaviour and reduces the symptoms of ADHD.

\section{Conclusion}

Many animal therapy studies point to a wide range of health benefits for people involved in treatment, but many of the researches are characterized by small interventions in various areas, resulting in criticism of poor study design or inconsistent methodology. Such criticisms contradict the strong claim among many that animal interaction has a strong and innate value to those involved. And our study is characterized by a small sample and a short period of intervention. To fully integrate animal therapy into practice as an accepted therapeutic modality, more convincing studies are needed to confirm clinical values, along with understanding the basic mechanism of human reaction to the presence of animals.

\section{References:}

Alliance OF Therapy Dogs. (2018, July 11) A History of Animal-Assisted Therapy. Retrieved [2020, May] from URL: https://www.therapydogs.com/animal-therapy/

American Veterinary Medica Association. (2019) Animal-assisted interventions: Definitions. Retrieved [2020, May] from URL: https://www.avma.org/resources-tools/avma-policies/animal-assisted-interventions-definitions

BAUN, M.M., MCCABE, B.W. (2000) The role animals play in enhancing quality of life for the elderly. Academic press.

BECK, K. R. (2015, April 4th) The Impact of Canine-Assisted Therapy and Activities on Children in an Educational setting. Retrieved [2020, May] from Fisher Digital Publications at St. John Fisher College: 
https://fisherpub.sjfc.edu/cgi/viewcontent.cgi?article=1313\&context=edu cation_ETD_masters

ClonowsKI, J. (2015, September 16) Therapy dogs - The Different types and their benefits. Retrieved [2020, May] from Feinberg consulting, Available from URL: https:/feinbergconsulting.com/therapydogs-thedifferent-types-and-their-benefits/

Elmaci, D. T., \& CevizCI, S. (2015, May 12th) Dog-Assisted Therapies and Activities in Rehabilitation of Children with Cerebral Palsy and Physical and Mental Disabilities. Retrieved [2020, May] from NCBI National Library of Medicine:

https:/www.ncbi.nlm.nih.gov/pmc/articles/PMC4454953/\#B12-ijerph12-05046

Fine Aubrey. (2000) Animal assisted therapy - Theoretical foundations and Guidelines for practices. Academic press.

HARrison, P. L., \& OAKLAND, T. (2000-2003) Adaptive Behavior Assessment System. USA: Western Psychological Services.

HOWELl-Forbes, E., MARXEN, K. (2014) Animal-Assisted Therapy: A Dog's Influence on Occupational Therapy Outcomes of a Child with Cerebral Palsy. University of Puget Sound.

Kruger, K. A., \& Serpell, J. A. (2006) Animal assisted interventions in mental health. In Handbook on Animal-Assisted Therapy: Theoretical Foundations. London: Academic Press.

LaFrance, C., Garcia, L., \& Labreche, J. (2007, May-June 3rd) The effect of a therapy dog on the communication skills of an adult with aphasia. Retrieved [2020, May], from NCBI National Library of Medicine National Institutes of Health:

https:/www.ncbi.nlm.nih.gov/pubmed/16950329/

LeVInson, B., MALlon, G. (1997) Pet-oriented child psychotherapy. Springfield, IL: Charles C. Thomas.

Pillow-Price, K., YontS, N., \& Stinson, L. (2014) Sit, Stay, Read: Improving Literacy Skills Using Dogs. Dimensions of Early Childhood, 42(1), 5-9.

SCHUCK, S., EMmerson, N., Fine, A., LAKES, K. (2015) Canine-Assisted Therapy for Children With ADHD: Preliminary Findings From The Positive Assertive Cooperative Kids Study. In J Atten Disord. 2015 Feb; 19(2): 125-137.

Tepfer, A., Ross, S., MacDonald, M., Ruell, M. A., RuauX, C., \& Baltzer, W. (2017, April 27th) Family Dog-Assisted Adapted Physical Activity: A Case Study. Retrieved [2020, May] from MDPI:

https://www.mdpi.com/2076-2615/7/5/35/htm\#B45-animals-07-00035 